\title{
Evaluating public leadership: towards an assessment framework
}

\section{Paul 't Hart}

To cite this article: Paul 't Hart (2011) Evaluating public leadership: towards an assessment framework, Public Money \& Management, 31:5, 323-330, DOI: 10.1080/09540962.2011.598338

To link to this article: https://doi.org/10.1080/09540962.2011.598338

曲 Published online: 04 Aug 2011.

Submit your article to this journal

Џlll Article views: 1427

Q View related articles $\sqsubset$

4 Citing articles: 10 View citing articles 


\section{Evaluating public leadership: towards an assessment framework}

\section{Paul 't Hart}

How can we tell good from bad leadership? This crucial normative question is too

often overlooked in public sector leadership theory and practice. This article

develops a general evaluation framework which suggests that effective public

leaders are those who are able to continuously strike a viable balance between the requirements of prudence, support and trustworthiness.

\section{From hero to villain, and back}

Was Rudy Giuliani a successful leader of New York City's metropolitan government? His commercial success as a 'leadership guru' certainly seems to suggest so: his book, simply entitled Leadership and containing $10 \mathrm{key}$ principles he said he had discovered and lived by throughout his long public career, sold millions of copies. Most buyers of that book probably did so because Giuliani was widely credited with responding calmly, energetically, empathically, and with dignity to the horrors of the 9/11 attack on the Twin Towers. But had that attack not happened as it did, at the tail end of his two terms as mayor of New York, would we still be turning to Giuliani's advice on how to lead in such numbers? Would he have been a credible Republican party contender for the presidential nomination in 2008? The answer to both these questions is probably a resounding 'no'. Giuliani's star had been sinking prior to $9 / 11$. He was embroiled in personal scandal, and public respect for his considerable achievements in restoring law and order in the city of his public prosecutor and early mayoral days had long made way for disenchantment with his authoritarian style, and with his lack of effectiveness in addressing the city's infrastructure, educational and social problems. Moreover, the firefighters' union of New York opposed his presidential nomination bid. The union released a video blaming Giuliani for the lack of investment in their communications equipment after the 1993 al-Qaeda attack on the World Trade Center had demonstrated that their radios were deficient. The video claimed that hundreds of firefighters died needlessly on $9 / 11$ because the order to evacuate the towers before their collapse never got through to them, following Giuliani's unwillingness to upgrade the equipment.

Christine Nixon was Australia's first female police chief. Transferring from the New South
Wales police into an appointment as chief commissioner of Victoria in 2001, she inherited a force marred by internal in-fighting and high levels of community dissatisfaction and mistrust. When she resigned eight years later to become head of the Victorian Bushfire Reconstruction and Recovery Authority, which had been established following devastating bushfires on the outskirts of Melbourne, she had become an icon. She was widely credited with enhancing her force's effectiveness (crime rates dropped dramatically during her tenure, as did road tolls), especially in long-neglected areas like the management of family violence. She transformed the police's standing in the community and put an end to a bloody gang war. Her participative leadership style, and her toughness in taking on rogue elements within the force, constituted a cultural challenge to the established ways of the organization. Upon her departure in March 2009, tributes flowed in from all sides.

One year later, however, public perceptions of her leadership changed dramatically. During hearings set up to investigate the February 2009 bushfires, it transpired that Nixon-the state's designated emergency response coordinator-had not been in the operations centre when the fires hit the townships and started killing large numbers of people, going to the hairdresser's and then out with friends instead. Her defence, that she had made appropriate delegations and had been contactable by mobile 'phone, was to no avail. The court of public opinion had already passed its verdict. A few months later her legacy was further clouded by the collapse in court of a high-profile internal investigation into a number of allegedly bent, leaking and even murderous officers on the force, which she had strongly supported.

As one does over long political and public service careers, Giuliani and Nixon both
Paul 't Hart is Professor of Public Administration at the Utrecht School of Governance, which he joined in 2001. He is also associate Dean at the Netherlands School of Government in The Hague. 
stepped down with mixed track records. Both had faced bursts of intense media criticism, pushback from within their own organizations and some segments of the community. However, they had also enjoyed high-profile successes and had produced good-looking performance statistics. Both left 'unfinished business' and even some awkward 'skeletons in the closet' when they moved on. In all of this, they demonstrated highly different leadership styles: Giuliani was essentially a bully with charm; Nixon was essentially a nurturing visionary. To make it more complex, the appreciation of their styles and their effectiveness as leaders has been shifting over time. These shifts have not stopped and they are likely to continue.

We see the same for many public officeholders. For example many, except for the most iconic and most vilified, former US presidents move up and down the rankings of the 'historical greatness' polls regularly conducted among both academic experts and the general community. These shifts are not the result changes in these leaders' own performances-they are, after all, retrospective judgments. In a limited number of cases (such as Richard Nixon's), they are caused by new information about those performances becoming public. The appreciation of Dwight Eisenhower, written off for decades as a donothing president, changed when newly-available archival materials revealed that, behind the scenes, Eisenhower had actively and cleverly steered the ship of state. Now dubbed 'the hiddenhand president' (Greenstein, 1987), he has shot up in the rankings.

The most important cause of changes in the assessment of leaders is the result of shifts in the kinds of criteria used to assess them. These shifts are a product of the passing of time, which brings changes in values, cultures and dominant coalitions. One citizen's and one era's heroleaders are another's mere triers, and yet another's wreckers. Talking about success and failure of public leadership is, therefore, a complex and tricky business. It is subject to all the vagaries of evaluation: multiple, conflicting, ambiguous, shifting criteria, applied by often all but disinterested assessors who form judgments in the face of partially incomplete, contradictory and contested information (see, for example, Bovens et al., 2006). At the very least, we should be very clear about the kinds of criteria we apply, how we gather evidence to assess performance against them, and what 'don't knows' and counterfactuals we absorb into the assessment.

Engaging in assessments of public leadership should logically precede any effort to prescribe to others how to best lead (and what to avoid). In practice, this is rarely the case. There are more than 15,000 leadership books and many more journal and magazine articles, scattered across a wide range of social science disciplines and covering a wide range of social spheres. It is fair to say that a significant majority of these publications aims to teach readers how they can become better leaders. But few examine the question that precedes these how-to prescriptions: how do we define and assess leadership success? (See Lord, 2001; Nye, 2008; Masciulli et al., 2009.)

We cannot simply equate successful leadership with successful political, policy, or organizational outcomes. The corporate literature suggests that it is difficult to demonstrate unequivocally that a chief executive officer's (CEO's) performance affects business performance: there are simply too many intervening factors to make straightforward and strong causal connection plausible. The same can be said of political and administrative leaders: who leads matters for some issues some of the time, but is extremely unlikely to be decisive on all issues governments deal with all of the time. Contextual and institutional factors loom large in contemporary assessments of governance success and failure (Feit, 1978; Blondel, 1987; Hargrove and Owen, 2003; 't Hart, 2011). Moreover, in a world in which public leadership roles are widely dispersed, institutional outcomes have many (co-)authors. Particularly in today's complex, networked public sector environment, different leaders may work at cross-purposes, or actively complement one another (Brookes and Grint, 2010). All this makes the question of leadership assessment a vexing one, which is perhaps precisely why so many leadership studies have shied away from posing it in the first place.

Although this may be understandable, it is a problematic omission. Without a proper normative grounding and systematic evaluation processes, leadership prescriptions are prescriptions without a diagnosis. This article addresses both sides of the assessment coin: assessing outcomes and ways of achieving desired outcomes. First I examine how we might evaluate the performance of public leaders and, more generally, the exercise of public leadership. Thinkers, researchers, and practitioners-have addressed it over the centuries, and there is no single and straightforward criteria set. Our expectations of leaders and leadership are embedded in our underlying ideas about good government. To do justice to this normative complexity, I will propose a multidimensional assessment framework. This framework does not get rid of the inevitable trade-offs, but it helps 
us bring them out into the open and force us to acknowledge that even the most impressive feats of leadership tend to come at a price, and that few leaders fail completely and utterly in each and very relevant respect. It also allows us to see how different types of public leaders_-political, bureaucratic, civic - face different performance tests.

Then I turn to the million dollar question: how can we bring about good public leadership, or at least avoid seriously 'bad' leadership? Book after book after book has been filled with exhortations and admonitions designed to help would-be leaders flourish. Most of these focus on the personal traits, skills and behaviours of CEOs in business, heads of government, senior public servants or heads of non-profit agencies. Some of this advice rests on contingency approaches where the trick is to get leaders to match their cognitive and behavioural styles to the kinds of context, issue or constituents they might be dealing with in different roles or at different times. Some of this how-to work rests on painstaking experimental work in the laboratory. Some is grounded in large-number comparative case research. However, too many are grounded in the personal, idiosyncratic experiences of veteran leadership practitioners and the pet models of senior consultants. They have great stories to illustrate their points, but much of their advice lacks robust empirical corroboration. This makes the prescriptive component of leadership studies an essentially non-cumulative knowledge enterprise. The airplay enjoyed by leading texts is more dependent on the celebrity of the author, than the independently assessable quality of the research underpinning the muscular prose that these books specialize in. Importantly for our present purposes, virtually none of these studies seriously addresses the specific context and challenges of public leadership.

\section{The public leadership assessment triangle}

Where to begin? There are so many different routes to arrive at criteria for evaluating public leaders and leadership. Why not keep it simple and focus the effort on what happens to officeholders themselves as a result of the way they do their jobs? The leader-centric perspective looks at the extent to which leaders are able to consolidate their positions through (re)election and (re)appointment, on the idea that good leaders thrive and bad leaders fall. Length of tenure, and formal judgments passed by electors, boards, and peers then become pivotal to assessing leaders, as does the reputation for influence they develop. We could also adopt a follower-centric perspective and focus on the extent to which leaders are perceived to satisfy their followers' needs and wants, as reflected in constituents' assessments of their values, character and above all their performance in the job. Or an institutional perspective, where good leadership is indicated by the legitimacy, performance and continuity of public organizations. The list of possibilities is long, but what is lacking is a common denominator that can meaningfully be applied to all forms of public leadership (political, administrative, civic - see 't Hart and Uhr, 2008). To develop such a generic model, I draw upon some of my prior work as well as that of others which assesses public leadership within a broader perspective on effective, democratic governance and public management (Moore, 1995; Hargrove, 1998; Bovens et al., 2001; Wren, 2007; Bovens et al., 2008; Kane et al., 2009). This work suggests that public leadership assessments need to take into account three families of core criteria:

- Impact: the value of the community and/or organizational outcomes that can be attributed to leaders' postures, decisions and actions.

- Support: the responses leaders evoke in both their authorizing (i.e. superiors, boards, legislatures, the general public) and their network (i.e. partners, stakeholders) environments.

- Trustworthiness: the degree to which leaders can be said to respect the responsibilities attached to their roles, including observing the institutional limitations placed upon their exercise of these roles.

The criteria are mutually supplementary, but also harbour potential trade-offs. They can be thought of as points in a triangle, with the sides of the triangle constituting the balancing act that public leaders continuously have to engage in when trying to reconcile conflicting imperatives in how they operate (compare George, 1980; Janis, 1989).

\section{Impact: consequential leadership}

In the first perspective the preoccupation is with what philosophers since Plato have grappled with: the need to make sure that the people at the top are people who govern wisely-not just courageously but smartly, realistically and with a sense of proportion and reflection-so as to improve the lot of the community (Keohane, 2005). Effective leadership enhances the community (be it a single organization, a network of organizations, 
or local, regional, national and international collectivities) capacity to come up with clever solutions to complex predicaments and adapt to changing circumstances. Public leadership structures and processes should facilitate this key aim, which is to be achieved by maintaining and strengthening their learning capacity (Heifetz, 1994; Van den Berg, 1999, p. 40; Aucoin and Heintzman, 2000, pp. 52-54).

Effective leadership mobilizes collective wisdom, that elusive and intricate mix of analytical judgment, discernment, intuition and comprehension. In the public sector, such wisdom should not be thought of as residing in any single public office-holder, however gifted and experienced they might be. Wisdom cannot exist in a social vacuum. It comes from critical reflection, from dialogue and dialectics, and presupposes leaders who accept, manage and negotiate difference-who organize diversity 'in' rather than 'out' of the policy-making process (Korac-Kakabadse et al., 2001), and thus organize what Lindblom (1965) long ago called 'the intelligence of democracy'. Public office-holders need to display continual awareness that they inhabit a world in which they are not the only people able to influence events. For one, they know they need to produce and consider public feedback about their own performance (Behn, 2001). The possibility of sanctions from clients and other stakeholders in their environment motivates them to search for more intelligent ways of organizing the public's business. It teaches leaders what is expected of them, what works and what doesn't. Second, an awareness of the fundamentally collective nature of social problem solving spurs leaders to shun thinking of their role as being that of the purveyor of 'solutions', which need to be sold to or imposed upon 'followers' (citizens, stakeholders, implementors). Effective public leadership is about provoking, enabling, protecting the work others need to do to enable the community as whole to address their most significant challenges.

\section{Support: accepted leadership}

The criterion of support, rooted in the work of scholars like Rousseau and Weber, holds that the core animating principle of contemporary democratic government is popular sovereignty, the idea that the people should rule. Naturally those in senior leadership positions exercise far more public authority than the ordinary citizens who technically are their ultimate authorizers. A permanent tension therefore exists between the leader and the sovereign community members. This engenders the kind of suspicion of leadership which has generated centuries of efforts to curb public power by fragmenting it and surrounding governments with institutional watchdogs to which they owe various forms of accountability. The fact that this key tension is, in principle, irresolvable gives public leadership its special character.

Popular sovereignty in practice takes the form of a chain of delegation, which can run all the way from citizens to legislatures to political executives to administrative agencies to private (non-profit and for-profit) public service providers. This idea has been refined in the principal-agent model, according to which a modern representative democracy can be described as a concatenation of principal-agent relationships (Strøm, 2000, 2004; Lupia, 2003). The people, who are the primary principals in a democracy, have transferred their sovereignty to popular representatives, who, in turn, have transferred the drafting and enforcement of laws and policy to the government. Ministers subsequently entrust policy implementation to their ministries, who proceed to delegate parts of these tasks to more or less independent bodies and institutions. Public servants at the end of this chain of delegation end up spending billions in taxpayers' money, using their discretionary powers to, among many other things, furnish licences and subsidies, distribute benefits, impose fines, prosecute people, and keep them locked up.

Each set of principals in the chain of delegation seeks to monitor the execution of the delegated public tasks by calling the agentleaders to account. At the end of the chain are the citizens, who pass judgement on the conduct of those leaders and who indicate their displeasure by voting for others. Hence citizens and their most directly elected representatives should be able to assess and express their support (or lack of) for how the full range of public office-holders exercise political and administrative leadership (Przeworski et al., 1999).

The principal-agent model focuses on the hierarchical nature of leadership mandates. In the contemporary world of networked governance, this is only a small part of the story of generating support for public leadership. In network settings, interdependence rather than hierarchy is the basic organizing principle. Networks form around issues, places, and (groups of) clients. They transcend existing political and bureaucratic jurisdictions: no single authority is formally and exclusively 'in charge'; responsibilities and resources for addressing the network's defining challenges 
are distributed. Order is fundamentally negotiated, and the acceptance of leadership in networks does not rely upon the power to decide and impose, but on the ability to seduce parties to commit to the network process and to orchestrate helpful dialogue and cooperation between them.

Good leaders in this perspective are those that maintain two positive relational balance sheets-one in the world of authorization, the other in the world of collaboration. That is a tall order. As well documented by Moore (1995) and Bennington and Moore (2010), just maintaining support within a complex and diverse authorizing environment is a challenging task for a political or administrative leader. Doing so while simultaneously building and maintaining the support of parties whose collaboration they need to achieve results but cannot commandeer, is outright tricky. When push comes to shove, many political and bureaucratic leaders shy away from it when they sense that their authorizers don't see eye to eye with their partners. Usually, they choose to appease the former at the price of diminishing their credibility with the latter. This is a key reason why many 'joined-up', 'collaborative' governance efforts are stillborn or peter out. As the former head of the Australian public service put it: 'Genuine collaboration...requires public servants who, with eyes wide open, can exert the qualities of leadership necessary to forsake the simplicity of control for the complexity of influence...[T]hey need to operate outside the traditionally narrow framework of government, which they have for so long worked within' (Shergold, 2008, p. 21).

\section{Trustworthiness: accountable leadership}

The main concern underlying this perspective is that of preventing tyranny by absolute rulers, presumptuous elected leaders, or an expansive and 'privatized' executive power. This perspective answers the central question of leadership ethics-whether the distinctive features of leadership justify rule-breaking behaviour (Price, 2008, p. 34)-in the negative. More precisely, it claims that the judgment of whether that rule-breaking is warranted at any given time ought to be made only by leaders themselves, but first and foremost by constitutionally and/or democratically empowered 'legitimate value judges' that are able to hold office-holders accountable for the way in which they exercise leadership (Dror, 1986). The remedy against overbearing or improper government leaders is the organization of institutional countervailing powers. Other public institutions, such as an independent judicial power or a court of audit are to act as such, complementary to the voter, parliament, and political watchdogs. They are to be given the power to keep leaders in check. Good leadership requires that public officeholders respect and honour these accountability obligations.

So in the trustworthiness perspective, good governance arises from a dynamic equilibrium between the various powers (legislative; executive; judicial) within-and increasingly beyond-the state (see Witteveen, 1991; Braithwaite, 1997; and Keane, 2009 on the rise of 'monitory' democracy). It proposes that a polycentric polity in all its messiness is to be preferred over a monocentric one. This bias may be pitted against its others. These include the aristocratic idea that democracies amount to letting mediocrity reign. They also include the 'novo-Platonic' (Dror, 2001) notion that we have created utterly fragmented, inchoate, paralytic systems of governance prone to 'disjointed incrementalism', even in the face of complex challenges and urgent threats that require coherent and decisive collective action. Some of the latter preoccupations can be found in the many critical accounts of the growing size, prominence and complexity of the transparency and accountability 'industry' (overview in Bovens et al., 2008). They argue that in many democracies there are so many watchdogs trying to keep public leaders in check that the system as a whole has gone 'MAD' (suffering from 'Multiple Accountabilities Disorder', see Koppell, 2005). It can also be found within the US literature on the presidency, where proponents of strong presidential leadership routinely deplore the high and increasing institutional fragmentation of the American political system (Shapiro et al.,

Figure 1. The public leadership assessment triangle.

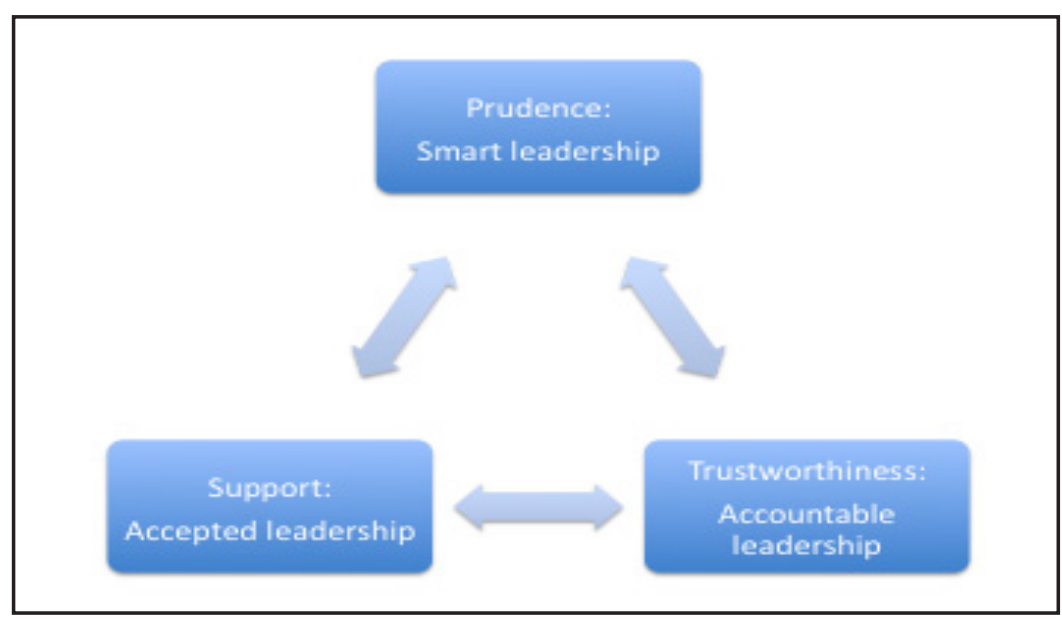


2000; Ellis and Nelson, 2010)—though this view has many detractors too, who are more concerned by undue concentration of power and authority in an 'imperial presidency' (Schlesinger, 1973; Edwards and Howell, 2009).

In sum, when each of the three perspectives assesses leadership, it applies distinctive yardsticks. Each yardstick also implies a set of distinctive preferences for particular ways of organizing leadership into the fabric of public institutions. Table 1 develops the leadership assessment triangle further.

\section{Leadership as balancing act}

Despite their different normative preoccupations, all three perspectives seem to agree on one fundamental thing: leadership is not a simple property of communities and public institutions. There is no simple 'more is better' or 'stronger is better' logic here. Rather, each of the criteria families realizes that it is too simple to argue that the higher the degree of leadership dispersal in a given polity, the more desirable that polity can be said to be. All of them seem to harbour a curvilinear view instead, in which there can also be 'too much' leadership: too élitist and too uniform; too opportunistic and populist; too isolated and unbridled (see also Kellerman, 2004). This becomes even clearer when we examine the built-in tradeoffs between the three criteria families

First, there is what we might call the Machiavellian trade-off between 'smart' (highimpact) versus accountable (trustworthy) leadership. It presents office-holders with the classic tradeoff between ends and means: how defensible is it to cut procedural and ethical corners in trying to achieve laudable objectives (Price, 2008)? Is it, for example, acceptable leadership practice for a minister seeking to attract a new, job-creating petrochemical plant to an economically-depressed region to rely on backroom dealing, and to manipulate public consultation processes to make sure that opponents of the new development will not be able to put up time-consuming and potentially deal-breaking planning and legal hurdles? Alternatively, how do you assess a minister who is so concerned about going by the book and remaining squeaky clean that he is reluctant to take any decision at all that is liable to legal challenge? What should be made of a senior public servant so concerned with bringing down the number of complaints to an ombudsman about her unit's decisions to repeal asylum claims that she instructs her staff to switch from a 'no, unless' to a 'yes, provided' posture, and apply it even to citizens from regions where current levels of human rights risk are widely deemed to be significantly decreased? She is evidently discounting the risk of unwittingly sending a signal of encouragement that might jeopardize the larger policy settings of the government-but how, and when, are we to judge the wisdom of that judgment call?

Second, there is the equally classic trade-off between acceptable (supported) versus 'smart' leadership. This tension is evident in times of austerity and international tension, for example. Take a country like debt-ridden Greece. For many years, the few Greek leaders who prudently advocated major cutbacks in public

Table 1. Evaluating public leadership: elaborating the three criteria families.

\begin{tabular}{|c|c|c|c|}
\hline & Impact & Support & Trustworthiness \\
\hline Key criterion & $\begin{array}{l}\text { Leaders to be instrumental in } \\
\text { organizing 'smart' collective } \\
\text { problem-solving }\end{array}$ & $\begin{array}{l}\text { Leaders to retain necessary } \\
\text { support for process and } \\
\text { content of the social problem- } \\
\text { solving efforts there are } \\
\text { invested in }\end{array}$ & $\begin{array}{l}\text { Leaders' power to be checked } \\
\text { by multiple, overlapping } \\
\text { accountability requirements }\end{array}$ \\
\hline \multirow[t]{2}{*}{ Operational indicators } & $\begin{array}{l}\text { Process: } \\
\text { Soliciting well-informed and } \\
\text { meaningful participation in } \\
\text { decision-making } \\
\text { Tolerance for cognitive and } \\
\text { value complexity } \\
\text { Effective management of self } \\
\text { Political skill }\end{array}$ & $\begin{array}{l}\text { Process: } \\
\text { Level and quality of engagement } \\
\text { with authorizing actors and bodies } \\
\text { Level and quality of engagement } \\
\text { with network partners }\end{array}$ & $\begin{array}{l}\text { Process: } \\
\text { Observance of institutional role } \\
\text { requirements in exercise of the } \\
\text { office } \\
\text { Mode of handling role } \\
\text { conflicts and/or ethical } \\
\text { dilemmas }\end{array}$ \\
\hline & $\begin{array}{l}\text { Outcomes: } \\
\text { Effectiveness of efforts to } \\
\text { tackle core community challenges } \\
\text { Efficient use of public resources }\end{array}$ & $\begin{array}{l}\text { Outcomes: } \\
\text { Alignment of authorizing } \\
\text { environment's willingness to sustain } \\
\text { the office-holder with network } \\
\text { partners'appreciation of } \\
\text { office-holder's facilitative role }\end{array}$ & $\begin{array}{l}\text { Outcomes: } \\
\text { Absence of illegality, scandal } \\
\text { and 'cover up' } \\
\text { Reputation for public } \\
\text { integrity }\end{array}$ \\
\hline
\end{tabular}


expenditure in order to reduce the stranglehold of escalating repayments and degenerating credit ratings risked political marginalization and popular revolt (quite literally). The need to retain office overcame the need to implement tough measures until the urgent risk of sovereign debt default changed the equation. Is this a leadership failure? Should, and could, the advocates of fiscal austerity have pushed much harder much earlier? It is easy to say so in hindsight. But could this not have been a case where the forces inducing leaders to be responsive to their domestic authorizing environment were simply overwhelming, crowding out the voice of reason and prudence?

Finally, the trade-off between acceptable and accountable leadership is one that is well-known to leaders of strongly client-centred public and non-profit organizations. The strong identification with the social mission of the agency, the psychological identification with the client base, or the (perceived) need to retain its cooperation and support at all costs may crowd out the salience of due process considerations. The leadership dilemma is what to do when pressures arise around condoning the cosy relationship by a rent-seeking clientele and the informal practices of rule application and service delivery that it has given rise to. Is it defensible to protect these informal arrangements from external scrutiny and resist pressures for change? Or does sound leadership require the agency executive to risk antagonizing the client base as well as its own front-line workers, and introduce an ethos of transparency, procedural propriety and more vigorous 'nay-saying'?

The triangle helps generating what I think are essential questions to ask when assessing public leadership performance. But it does not automatically provide the answers. Such answers cannot be given in the abstract. They need to be developed, and argued, in concrete instances of particular leaders dealing with particular issues at particular times. The framework alerts us to the multifaceted, inherently conflicted nature of public leadership roles and predicaments. It is a world of competing values (Quinn et al., 2006), with a specific public sector twist. Judging how well such leadership is being performed is almost equally 'messy'. It challenges the assessor to think carefully about what they value in public officeholders, and what trade-off choices they themselves are prepared to make in labelling some to be 'heroes' and others 'failures'.

A final interesting dimension of the assessment triangle is that it invites further thinking on how the three criteria families apply to three different types of public leadership commonly discerned in the literature: political, civic and administrative. Clearly, the nature and perhaps the relative weight of the criteria may differ across these categories. For example, where in a democracy obeying the law is crucial to underpin the trustworthiness of both political and bureaucratic leaders, the theory of civil disobedience creates a certain amount of 'wiggling room' in this space for civic leaders. Yet even so, the trade-offs generated by claiming this space can be stark, as Martin Luther King Jr and the other leaders of the movement for the emancipation of black Americans experienced. In fact, as happens in many other social movement leaderships, King and his colleagues were bitterly divided about precisely where to draw the line.

Likewise, for administrative leaders a key assessment trade-off is hidden in the familiar 'speaking truth to power' dilemma. How do we value the bureaucrat who prizes smartness and social impact above the need to be 'responsive' to and thus maintain the support of political masters who for whatever reason do not wish to pursue what she is convinced is the most socially effective course of action, and therefore 'goes public' or simply carries on pushing policies that the government of the day does not want implemented? How, in contrast, do we assess the leadership of her colleague who, faced with exactly the same dilemma, decides to get along by going along with the prevailing political winds? And what if it is not two bureaucrats but two ministers choosing different pathways to navigate the dilemma between the preferences of their principals' (for example voters, party bosses, parliament, the prime minister) and their policy convictions (or, indeed, the advice of their bureaucrats)? Do we value the 'courage' and 'authenticity' of the minister who does not succumb to 'poll-following', or do we lament their 'crusader mentality' or 'lack of a political antenna'? The point of the triangle is not that it can solve such evaluative conundrums. Its point is that it can help us foresee them and, as democratic communities, explore ways of addressing the conflict between different desiderata in making the concrete, context-specific judgments that leadership evaluation inevitably entails. 


\section{References}

Aucoin, P. and Heintzman, R. (2000), The dialectics of accountability for performance in public management reform. International Review of Administrative Sciences, 66, 1, pp. 45-56.

Bennington, J. and Moore, M. (Eds) (2010), Public Value: Theory and Practice (Palgrave, Basingstoke).

Berg, J.van den (1999), Verantwoorden of Vertrekken: Een Essay over Politieke Verantwoordelijkheid (VNG uitgeverij, The Hague).

Blondel, J. (1987), Political Leadership (Sage, London).

Bovens, M., 't Hart, P. and Kuipers, S. (2006), The politics of policy evaluation. In Goodin, R. E.etal.(Eds), Oxford Handbook of Public Policy (Oxford University Press, Oxford), pp. 317-333.

Bovens, P., 't Hart, P. and Peters, B. G. (Eds), (2001), Success and Failure in Public Governance: A Comparative Analysis (Edward Elgar Publishing, Cheltenham).

Bovens, M., Schillemans, T. and 't Hart, P. (2008), Does public accountability work? An assessment tool. Public Administration, 86, 2, pp. 225-242.

Braithwaite, J. (1997), On speaking softly and carrying big sticks. University of Toronto Law Journal, 47, 3, pp. 305-361.

Brookes, S. and Grint, K. (Eds), (2010), The New Public Leadership Challenge (Palgrave, Basingstoke).

Dror, Y. (1986), Policy-Making Under Adversity (Transaction, New Brunswick).

Dror, Y. (2001), The Capacity to Govern (Frank Cass, London).

Edwards, G. and Howell, W. G. (Eds), (2009), The Oxford Handbook of the American Presidency (Oxford University Press, Oxford).

Ellis, R. J. and Nelson, M. (Eds), (2010), Debating the Presidency (Washington, D.C.).

Feit, L. (1978), Governments and Leaders: An Approach to Comparative Politics (Houghton Mifflin, Boston).

George, A. L. (1980), Presidential Decisionmaking in Foreign Policy (Westview, Boulder).

Greenstein, F. (1987), The Hidden-Hand Presidency (Princeton University Press, Princeton).

Hargrove, E. (1998), The President as Leader (Kansas University Press, Lawrence).

Hargrove, E. and Owen, J. (Eds), (2003), Leadership in Context (Rowman \& Littlefield, Lanham).

Janis, I. L. (1989), Crucial Decisions (Free Press, New York).

Kane, J., Patapan, H. and 't Hart, P. (Eds), (2009), Dispersed Democratic Leadership (Oxford University Press, Oxford).

Keane, J. (2009), The Life and Death of Democracy (W. W. Norton \& Company, New York).

Kellerman, B. (2004), Bad Leadership (Harvard Business, Cambridge).

Keohane, N. (2005), On leadership. Perspectives on Politics, 3, 4, pp. 705-722.
Koppell, T. (2005), Multiple accountabilities disorder. Public Administration Review, 65, 1, pp. 94-108.

Korac-Kakabadse, N., Kakabadse, A. and Kouzmin, A. (2001), Leadership renewal.International Review of Administrative Science, 67, 2, pp. 207-227.

Lindblom, C. E. (1965), The Intelligence of Democracy: Decision Making Through Mutual Adjustment (Free Press, New York).

Lord, C. (2001), The Modern Prince: What Leaders Need to Know Now (Yale University Press, New Haven).

Lupia, A. (2003), Delegation and its perils. In Bergman, T. et al. (Eds), Delegation and Accountability in West European Parliamentary Democracies (Oxford University Press, Oxford), pp. 33-54.

Masciulli, J., Molchanov, M. A., Knight, W. A. (Eds), (2009), The Ashgate Research Companion to Political Leadership (Ashgate, Aldershot).

Moore, M. (1995), Creating Public Value (Harvard University Press, Cambridge).

Nye, J. (2008), The Powers to Lead (Oxford University Press, Oxford).

Przeworski, A., Stokes, S. C. and Manin, B. (Eds), (1999), Democracy, Accountability and Representation (Cambridge University Press, Cambridge).

Price, T. L. (2008), Leadership Ethics: An Introduction (Cambridge University Press, New York).

Quinn, R. E.etal. (2006), Competing Values Leadership (Edward Elgar Publishing, Cheltenham).

Schlesinger, A. M. (1973), The Imperial Presidency (Houghton Mifflin, New York).

Shapiro, R. Y., Joynt Kumar, M. and Jacobs, L. R. (Eds), (2000), Presidential Power: Forging the Presidency for the Twenty-First Century (Columbia University Press, New York).

Shergold, P. (2008), Governing through collaboration. In O'Flynn, J. and Wanna, J. (Eds), Collaborative Governance (ANU E Press, Canberra), pp. 13-20.

Strøm, K. (2000), Delegation and accountability in parliamentary democracies. European Journal of Political Research, 37, 3, pp. 261-289.

Strøm, K. (2004), Parliamentary democracy and delegation. In Strøm, K. et al. (Eds), Delegation and Accountability in Parliamentary Democracies (Oxford University Press, Oxford), pp. 55-106.

't Hart, P. (2011), Reading the signs of the times: regime dynamics and leadership possibilities. Journal of Political Philosophy, 19, 1.

't Hart, P. and Uhr, J.(Eds), (2008), Public Leadership (ANU E Press, Canberra).

Witteveen, W.(1991),Evenwichtvan Machten (Tjeenk Willink, Zwolle).

Wren,J. T. (2007), Inventing Leadership: The Challenge of Democracy (Edward Elgar Publishing, Cheltenham). 